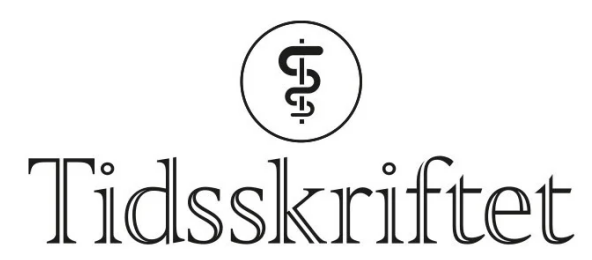

DEN NORSKE LEGEFORENING

\title{
Screening for kolorektal kreft
}

\author{
KOMMENTAR
}

\section{EIVIND MELAND}

Institutt for samfunnsmedisinske fag

Universitetet i Bergen

Kalfarveien 31

5018 Bergen

Det må stilles de samme krav om saklighet og sannferdighet til helsepersonell i myndighetsposisjoner som til øvrig helsepersonell. Screening for tarmkreft er som all annen individrettet screening beheftet med negative bivirkninger. Dette må vi være åpne om, slik at de som inviteres kan gi samtykke basert på balansert og saklig informasjon.

Nylig kom nyheten om at Helsedirektoratet støtter igangsetting av regelmessige screeningundersøkelser for tarmkreft for befolkningen i alderen 50-74 år. Gjennom nyhetssendingene har helsedirektøren meddelt at vi ved innføringen av dette tiltaket kan unngå 250 dødsfall årlig.

Han har derimot ikke gitt informasjon om at tiltaket kan kreve betydelige kostnader i form av personlige påkjenninger, både av fysisk og psykisk art. Etter min mening bryter helsemyndighetene på denne måten eklatant etiske regler for sannferdig informasjon og helsepersonellovens bestemmelser om full informasjon og rett til å velge utredning og behandling basert på informert samtykke. Jeg har tidligere bedt Legeforeningens etiske råd om å ta initiativ til at screeningtiltakenes informasjonsmateriell og invitasjoner til deltakelse gjøres saklige, balanserte og med en erklært aksept for at det er mulig å avstå (ㅁ). Det er gjort noen endringer til det bedre, men de er ikke tilstrekkelige. Fortsatt sitter man igjen med et inntrykk av at totalmortaliteten går ned ved mammografi- og cytologiscreening.

Derfor er det nødvendig at Legeforeningens etiske råd og påtalemakten nå følger denne saken nøye og påser at Legeforeningens etiske regler og helsepersonellovens bestemmelser blir innfridd. Vi kan ikke leve med at leger i myndighetsposisjoner skal være fritatt for å følge foreningens etiske regler og norsk lovverk.

\section{Ikke redusert dødelighet}


Tarmkreftscreening har ivrige forkjempere, og argumentene for å iverksette dette tiltaket ble nylig fremført i en kommentar i Tidsskriftet (1). Internasjonalt er skepsisen mot slike helsetjenestetiltak økende, og i lederartikler både i The Scandinavian Journal of Primary Health Care og i The Lancet er negative effekter resymert og det manes til edruelig informasjon før informert samtykke innhentes $(\underline{2}, 3)$. Da ingen studier kan påvise effekt på totaldødelighet, må ikke informasjonsmateriellet inneholde påstander om at liv blir spart. Ingen studier har kunnet påvise dette. Riktignok kan man argumentere med statistisk tilfeldighet og type 2-feil, fordi det ville krevd svært store studier for å oppnå statistisk styrke nok når den spesifikke dødeligheten utgjør bare en liten del av totaldødeligheten. Men dette kan ikke brukes som argument for å fremme usanne påstander om at vi kan unngå dødsfall.

Man finner riktignok en reduksjon i spesifikk dødelighet i de fleste studier av screeningprogrammer for tarmkreft. Men det er altså antall dødsfall av tarmkreft, ikke antall dødsfall generelt, som kan reduseres. Deltakerne må informeres om dette. De må også informeres om at de fleste som får påvist blod i avføringen ikke har tarmkreft, og at koloskopi og fjerning av polypper innebærer en viss risiko. De må også vite at alle polypper fjernes selv om de bare helt unntaksvis utvikler seg til kreft, og at en fjerning øker faren for blødning og perforasjon. Slike komplikasjoner kan være dødelige. Dertil kommer at deltakere som får påvist blod i avføringen, kan oppleve emosjonelt ubehag i ventetiden på videre unders $\emptyset$ kelse. Selv om psykiske langtidsvirkninger av falsk positivitet ved tarmkreft er mangelfullt undersøkt, er det grunn til å anta at et betydelig antall personer påføres lidelse som kan vare i lengre tid (4).

Informasjonsmateriellet bør også eksplisitt tilkjennegi at dette helsetjenestetiltaket bygger på en instrumentell forståelse av helse og at en slik helseforståelse kan undergrave takknemligheten til og opplevelsen av livet som gave.

\section{Samfunnets terapeutisering}

Det er tydelig at helsemyndighetene foreløpig ikke har villet se selvkritisk på hvilken grunnleggende forståelse av helse de bygger sin virksomhet på. De tar for gitt at helsen fremmes ved å stimulere til dødsangst og ved å tilby tekniske og individualiserte tiltak til et umettelig kontrollbehov, som de selv skaper. Det er dette som ifølge den kanadiske filosofen Charles Taylor er selve grunnlaget for terapeutiseringen i det sekulære samfunnet. En slik terapeutisering er ifølge Taylor en mager religionserstatning. Det fører til en grunnleggende falsk selvforståelse, et isolert, ensomt og polstret selv, og man mister kontakt med livets grunnvilkår og med opplevelsen av livet som gave. Det blir vanskelig og umulig å oppleve selvet som tilhørende i og holdt oppe av naturen og skaperverket (5). Det er på høy tid at helsemyndigheter, politikere og akademi tar inn over seg Taylors sekularitetsanalyse med det mål for øye å utvikle nye forståelser av og praksiser knyttet til helse. Det er ingen skam å snu!

\section{Oppgitte interessekonflikter:}

Ingen

\footnotetext{
LITTERATUR

1. Hoff G. Screening for kolorektalcancer haster. Tidsskr Nor Legeforen 2010; 130: 925.

2. Centres R. The trouble with screening. Lancet 2009;373: 1223.

3. Getz L, Brodersen J. Informed participation in cancer screening: the facts are changing, and GPs are going to feel it. Scand J Prim Health Care 2010; 28: 1-3.
} 
4. Brodersen J. Measuring psychosocial consequences of false-positive screening results - breast cancer as an example. København: Københavns universitet, 2006.

5. Taylor C. A secular age. Cambridge, MA: The Bellknop Press of Harvard University Press, 2007.

Publisert: 26. august 2010. Tidsskr Nor Legeforen. DOI: 10.4045/tidsskr.10.0556

Manuskriptet ble mottatt 11.5. 2010 og godkjent 10.6. 2010. Medisinsk redaktør Anne Kveim Lie.

(C) Tidsskrift for Den norske legeforening 2023. Lastet ned fra tidsskriftet.no 26. april 2023. 